DE DE GRUYTER

OPEN
Journal of Intercultural Management

Vol. 7, No. 1, January 2015, pp. 97-109

DOI 10.1515/joim-2015-0006

Iwona Gorzeń-Mitka*

Czestochowa University of Technology, Faculty of Management

\title{
Family Business to Improve Management Paradigm - Selected Cross-cultural Remarks
}

\begin{abstract}
Complexity and changeability of modern economic processes (especially in cross-cultural context) require enterprises to continuously improve their management processes. Family enterprises, which play an important role in economic growth of economies all over the world, constitute a group that is in especially susceptible to dynamism of changeability of the economic environment, because they mostly belong to the group of micro-, small and medium-sized enterprises. Improvement, which is becoming a key challenge for today's enterprises and constitutes a paradigm of modern management of an enterprise (also in cross-cultural management view), is especially visible in an analysis of this group of entities.

The aim of this paper is to confirm the thesis the characteristics distinguishing family firms from the others are determinants of improvement, which is a modern paradigm of management (also in cross-cultural context).
\end{abstract}

Key-words: family business, paradigm of management, improvement, management, paradigm of improvement, cross-cultural management

\section{Introduction}

Complexity and uncertainty which characterize the environment in which enterprises are functioning, force them to continuously improve and search for new, often unconventional solutions for shaping decision making processes. It refers both to organizational, technological and managerial solutions. In the situation of dynamically changing external and internal conditions of its functioning, an organization can survive and grow only when it is able to successfully adapt its changeability to the changeability of the environment in which it is operating

\footnotetext{
* iwona.mitka@zim.pcz.pl
} 
[Penc 2002, s.51]. Important element on this view are cross-cultural elements. The sector of micro-, small and medium-sized enterprises is the group of entities that is especially exposed to the effects of changeability of the environment. On the one hand, such enterprises constitute a "driver" of numerous countries' economies, on the other hand however, the scale of their resources, skills or possibilities of gaining access to capital [Okręglicka 2013, ss.74-84], information or innovation [Sipa 2013, ss. 119-128] is limiting the effectiveness of their actions to counteract threats [Gorzeń-Mitka 2013a, ss. 6-11]. Searching for ways to improve the activities of an organization, taking into account the existing constraints to its functioning (both internal and external ones) is becoming not only a challenge but even a paradigm of modern management [Gorzeń-Mitka 2013b, ss. 11-19]. The existing and applied systems of decision-making are often inadequate to the new challenges encountered by enterprises. This is stressed e.g. by D.Jamali [2005, ss.104-105] in his work Changing management paradigms: implication for educational institutions, who points out that improvement in this area is becoming a requirement that must be met by modern entities to be able to conduct business.

The aim of this paper is to point out that the specific features of family enterprises predispose them to fulfil the paradigm of management improvement (also in cross-cultural context) and they should be implanted also to the operation of other types of enterprises.

The scope of this discussion has been limited to identifying specific characteristics of family firms and explaining the main idea of the paradigm of management improvement. Against this background, the common features of the areas of family enterprise and paradigm of management improvement have been indicated as recommended for implementation in the practice of managing other types of enterprises.

As the paper functions as an illustration, the main method is overview of the literature of the subject in the selected scope of discussion. The paper has an element of novelty and originality in the fact that it points out that improvement, though "unnamed", is a subject of scientific discussion with the rank of a paradigm, and relates it to the specific features of family firms.

Specificity of management in family businesses - overview of selected studies Family enterprises are playing an important role in the economic growth of economies all over the word (they contribute to generation of $90 \%$ of global gross domestic product [FFI 2014]) and constitute a dominating form of organizations across the world (especially in developing countries). The percentage of registered companies which are controlled by families oscillates between $50 \%$ in the European Union and over 95\% in the United States, with 65-90\% in the Latin America [PwC 2008].

Family companies are usually defined as ones where a family exerts or has an effective control over the direction of the strategic development of the business, 
which in turn generates welfare to the family, its income or identity [PARP 2012,Sułkowski Marjanski 2009]. This interpenetration of the spheres of family and business makes family enterprises a special type of organizations.

The issues of the functioning of family enterprises and the impact of family relationships on business are the subject of a wide range of analyses. We can distinguish two main types of such analyses:

- analyses referring to the functioning of an enterprise as such (e.g. competitiveness and its determinants, innovation, etc.) and

- analyses specific only to family enterprises (e.g. the issues of success, etc.).

An example of studies of the first type is discussion raised by N. Bloom and J. Van Reenen [2006] and presented in their work entitled: Measuring and explaining management practices across firms and countries. The authors analyzed the impact of a management model on an enterprise's competitiveness. In their work they pointed out, among other things, that companies where the chief executive officer (CEO) is chosen by primo geniture tend to be poorly managed. At the same time, they stressed that ownership concentration in a family company may have a positive impact on reduction of the principal-agent problems [Gorzeń-Mitka 2007, ss. 57-58]. They also indicated that family ownership combined with professional management (i.e. when the chairman is not a family member) has a positive impact on implementation of good managerial practices. These observations are confirmed in, among other things, studies by E.Claver, L. Riend and D. Quer [2009, ss.125-135].

An example of studies of the second type is discussion raised by E. Brenes, K. Madrigal and G.Molin in their work entitled: Family business structure and succession: critical topics in Latin American experience [Brenes i in 2006, ss. 372-374]. Dotycza one dziedziczenia i kontroli kapitału, które to uznawane są za najważniejsze z czynników prowadzacych do problemów w przedsiębiorstwach rodzinnych. It is about capital succession and control which are regarded as the most significant factors leading to problems in family enterprises. In the Polish studies, these issues were discussed in the report Codes of values - effective succession in Polish family companies [Lewandowska 2013], which indicated main problems in this area.

According analyzing cross-cultural context of this area we can find following reflection. According Mine Karataş-Özkan K. et al. [2011], the study of diversity and impact of culture in family business research remains largely uninformed by critical perspectives on diversity in organizations and cultural embeddedness of organizational activity, reflecting the broader functionalist and normative paradigms that have dominated the subject domain.

The literature review helps identify the key issues of cross-cultural management of family firms has attracted considerable attention to academics and practitioners.

Another area within the field of family business that has attracted considerable attention is the role of non-family members in managing family firms [YildirimÖktem and Üsdiken 2009]. 
Management in a family enterprise is in some areas characterized by different features compared to other entities. Characteristic features of a family enterprise and the method of managing such an enterprise have been presented in table 1. The features have been grouped against variables characterizing other enterprises (i.e. ones that are not family companies) and cross-cultural view on management.

Table 1. Characteristic features of a family enterprise management - cross-cultural view

\begin{tabular}{|c|c|c|c|}
\hline & Family enterprise & Other enterprises & $\begin{array}{l}\text { Cross-cultural } \\
\text { view }\end{array}$ \\
\hline & \multicolumn{2}{|l|}{ Similarities } & \\
\hline Leading sector & \multicolumn{2}{|l|}{ MSME } & \\
\hline Company size & \multicolumn{2}{|l|}{ Similar } & \\
\hline Number of employees & \multicolumn{2}{|l|}{ Similar } & \\
\hline Activity area & \multicolumn{2}{|l|}{ Similar } & \\
\hline Volume of income & \multicolumn{2}{|l|}{ Similar } & \\
\hline \begin{tabular}{|l|} 
Investments and \\
development plans
\end{tabular} & \multicolumn{2}{|l|}{ Similar } & \\
\hline \multirow[t]{2}{*}{$\begin{array}{l}\text { Perceptions of key } \\
\text { barriers }\end{array}$} & \multicolumn{2}{|l|}{ Similar } & \\
\hline & \multicolumn{2}{|l|}{ Differences } & \\
\hline $\begin{array}{l}\text { Average time } \\
\text { functioning of the } \\
\text { company }\end{array}$ & $\begin{array}{l}\text { Long, generational } \\
\text { (average } 30 \text { years) }\end{array}$ & Short (average 5-9 years) & + \\
\hline Board company & Family Members & Other & + \\
\hline $\begin{array}{l}\text { Management } \\
\text { delegation }\end{array}$ & Succession & Other & - \\
\hline Business planning & $\begin{array}{l}\text { Long-term, at least } \\
\text { one generational }\end{array}$ & $\begin{array}{l}\text { Short-term, elective, } \\
\text { focusing on short-term } \\
\text { projects }\end{array}$ & + \\
\hline Financial management & $\begin{array}{l}\text { Careful, responsible, } \\
\text { focused on long-term } \\
\text { perspective }\end{array}$ & $\begin{array}{l}\text { Moderate, sometimes } \\
\text { risky }\end{array}$ & $\mathrm{N}$ \\
\hline Corporate reputation & $\begin{array}{l}\text { Important, often } \\
\text { fundamental }\end{array}$ & Moderate & - \\
\hline Corporate value & $\begin{array}{l}\text { Same among family } \\
\text { members }\end{array}$ & $\begin{array}{l}\text { Different, sometimes } \\
\text { only declared }\end{array}$ & + \\
\hline Organizational culture & $\begin{array}{l}\text { Specific, } \\
\text { Creating positive } \\
\text { atmosphere in the work } \\
\text { of all employees } \\
\end{array}$ & No dominant type & + \\
\hline $\begin{array}{l}\text { Personnel } \\
\text { recruitment }\end{array}$ & $\begin{array}{l}\text { Preferred family - } \\
\text { greater confidence }\end{array}$ & $\begin{array}{l}\text { Determine factors other } \\
\text { than family relationships } \\
\text { (qualifications, } \\
\text { experience, etc.) }\end{array}$ & $\mathrm{N}$ \\
\hline
\end{tabular}




\begin{tabular}{|c|c|c|c|}
\hline $\begin{array}{l}\text { Human Resource } \\
\text { Management }\end{array}$ & \begin{tabular}{|l} 
Personalized \\
relationships \\
with employees \\
(business or personal \\
relationships); \\
better recognition \\
capabilities of \\
workers, the \\
possibility of \\
individual adjustment \\
to the workplace, \\
higher efficiency
\end{tabular} & Business relationships & + \\
\hline $\begin{array}{l}\begin{array}{l}\text { Requirements of } \\
\text { employees }\end{array} \\
\end{array}$ & $\begin{array}{l}\text { Increased requirements } \\
\text { for family members }\end{array}$ & No preference & $\mathrm{N}$ \\
\hline $\begin{array}{l}\text { Communication } \\
\text { method }\end{array}$ & $\begin{array}{l}\text { Specific } \\
\text { easier to express } \\
\text { opinions, also negative }\end{array}$ & No dominant type & + \\
\hline Decision-making & $\begin{array}{l}\text { Quick, often do } \\
\text { not require formal } \\
\text { consultation with } \\
\text { other members of the } \\
\text { board (family) }\end{array}$ & $\begin{array}{l}\text { Requiring formal } \\
\text { consultation with } \\
\text { owner or board }\end{array}$ & + \\
\hline Risk management & $\begin{array}{l}\text { Intuitive } \\
\text { Use simple risk } \\
\text { mitigation methods }\end{array}$ & $\begin{array}{l}\text { Intuitive, often not } \\
\text { conscious }\end{array}$ & + \\
\hline \begin{tabular}{|l|}
$\begin{array}{l}\text { Contact with } \\
\text { customers }\end{array}$ \\
\end{tabular} & $\begin{array}{l}\text { High flexibility and } \\
\text { commitment }\end{array}$ & $\begin{array}{l}\text { Result of the business } \\
\text { model }\end{array}$ & + \\
\hline $\begin{array}{l}\text { Sensitivity of } \\
\text { economic changes }\end{array}$ & \begin{tabular}{|l} 
Low \\
Flexibility and quick \\
adaptation to changing \\
economic conditions
\end{tabular} & Significant & $\mathrm{N}$ \\
\hline $\begin{array}{l}\text { Responsibility for } \\
\text { employees, the local } \\
\text { community }\end{array}$ & High & $\begin{array}{l}\text { Result of legal norms } \\
\text { and practices }\end{array}$ & - \\
\hline
\end{tabular}

Legend: + favorable feature; - unfavorable feature; $\mathrm{N}$ - neutral feature.

Source: own study based on: PARP 2012; Bloom Van Reenen 2006; Sipa 2012, ss. 270 278; Gorzeń-Mitka 2013a, ss.6-11; Sułkowski 2010; Yildirim-Öktem Ö, Üsdiken B. 2009; Mine Karataş-Özkan et al. 2011.

Although in many areas the functioning of a family enterprise (including crosscultural aspects) does not differ from the way business is conducted in other types of enterprises (see table 1: similarities), the specificity of connections between the family and business spheres has a significant impact on how family enterprises are managed (see table 1: differences). In further sections of the paper, the author will 
attempt to relate the specificity of managing a family enterprise to the postulates of the paradigm of management improvement.

\section{Improvement as a paradigm of managing a modern enterprise}

In his book „The structure of scientific revolutions”, T. Kuhn defines the concept of paradigm as certain knowledge comprising scientific opinions, theories and methodologies of action that lead to acquiring knowledge that is certain [Kuhn 1970]. In „Aspekty złożoności i filozofii nauki w zarządzaniu” T. Gospodarek [2012, s.299] points out that paradigm is a certain scientific proposition; it may be both falsified and validated and constitutes certain knowledge with established high degree of acceptance. In particular, in management sciences knowledge building must be based on self-adaptable processes of improving the systems of paradigms and observation-based facts [Gospodarek 2012, s.308]. The process of discussion adopted by the author seems to meet this postulate. It should be stressed at this point that the growing gap between management theory and business practice that has emerged over the years led to the development of a new paradigm which should ensure constructional coherence of these areas. At the foundation of this paradigm, there are four aspects of present reality: customer needs, quality, systemic management, and innovations. As stressed by B. Słowiński changes in the paradigm are manifested in many aspects connected with the functioning of an enterprise: e.g. in the change of an enterprise's organizational structure where we see a change from a functional (characteristic for the "classical" approach) structure to process-based or network structures which are characterized mainly by flexibility and adaptability to changes in the environment [Słowiński 2009, s.21].

Recently, we have been observing in academia a return to discussions on paradigms in management. Such discussions have been raised e.g. by W.M Grudzewski and I.K.Hejduk who postulate that the specific paradigm of modernity is sustainability [Grudzewski Hejduk 2011, s.102] and by Ł. Sułkowski who has presented different typologies of organization paradigms in his work entitled: Paradigms of management sciences [Sułkowski 2013, ss.17-26].

The issue of improvement [Tatarkiewicz 1976, Arystosteles 1996] with reference to management sciences has been present for a long time, and its understanding has evolved over the years. The changes concerned both the subject and methods of improvement [Gorzeń-Mitka 2013, s. 11-19]. Improvement, although it had been present in earlier discussions of researchers, was first stressed and presented by T.J. Petersa i R.H. Watermana Jr. They suggested that perfect companies are those which have a long successful history and do some things in a systematic way that distinguishes them from other companies [Peters Waterman 1982, Peters Austin 1985]. They claim at the same time that ,perfect companies are first of all brilliant at the fundamental level. Tools cannot substitute thinking [...] These 
companies work hard so that things (solutions) remain simple in the complicated world. They preserve them. The rely on the highest quality. They observe (notice) their customers. They listen to their employees and treat them as adults"[Peters Waterman 1982, s.13].

Nowadays, hyper-competition and constant pressure on long-term increase in an enterprise's value force enterprises to search for more and more effective solutions to continuously improve and enhance the existing processes. The process of changes (including cross-cultural changes) and improvement has become part of the day-to-day operation of an organization. The process of improvement should allow a company to eliminate existing problems, reduce its weaknesses and identify new areas of strengthening its competitive advantage. Thus, a perfect organization is one that continuously extends its capabilities and uses them to overcome challenges that appear, and is able to identify and exploit emerging opportunities and possibilities to gain a sustainable competitive advantage. It is an organization that is always prepared to recognize threats and minimize risk [Lisiecka 2006, s.301].

As J. Ejdys points out, in management sciences the terms "perfection" and "improvement" are inseparably connected with the process of development of a given organization. However, while the need for changes as such seems to be indisputable, how these changes will be introduced is a question of choice [Ejdys 2011, s.105].

The concept of continuous improvement is applied in many tools and organizational solutions, and is used with reference to various areas of an enterprise's activity such as: manufacturing of products, processes and relations between them, organizational structures, management systems, human aspects and culture, infrastructure, work environment and technologies, as well as relations with relevant interested parties**.

At the end of the discussion on the paradigm of perfection and improvement in management we should highlight the contribution of W.E. Deming. His examination and proposed solutions constitute the basis of numerous theoretical models of improvement. The PDCA (Plan-Do-Check-Act) cycle created and proposed by him, when applied within a given organizational culture [GorzeńMitka 2013c, pp.21-32] not only makes it easier to improve management but also makes it possible to consolidate the habits of continuous improvement[Broniewska 2007]. According to W.E. Deming, the knowledge about the subject of improvement comprises four basic elements: theory of systems, theory of changeability, theory of knowledge and psychology, and these elements overlap and complement each other. The knowledge of systems allows one to navigate in the real world of an

\footnotetext{
** More details in: PN-EN ISO 14004; PN-EN ISO 9000, PN-EN ISO 9004, PN-N 18004.
} 
organization functioning on the market and processes being improved. Knowledge of the theory of changeability enables one to learn the ways of examining the causes of event randomness and minimize their impact on a process. Knowledge of the theory of knowledge enables systematic and effective use of the achievements of the mankind. Finally, knowledge of psychology is necessary for finding out the sources of motivation of human beings and managing them in a way that is most optimal for them and the organization (especially in cross-cultural aspects). Only when these theories are simultaneously taken into account, it is possible to achieve success [Ejdys 2011, p. 109].

M. Rungtusanatham, C. Forza, R. Filippini and J.C. Anderson in their work entitled: "A replication study of a theory of quality management underlying the Deming management method: insights from an Italian context" [ Rungtusanatham et al. 1988, pp.77-95] identified common features of management concepts based on the theory of continuous improvement by W.E. Deming. They include:

- visionary leadership,

- internal and external cooperation;

- learning;

- cross-cultural elements;

- management of processes;

- continuous improvement;

- employees' satisfaction;

- customers' satisfaction.

The set of these features, in the author's opinion, is at the same time a group of assumptions that should constitute a model of an enterprise management in accordance with the paradigm of improvement.

Family enterprise as a paradigm of improvement

The specific features of family enterprises, as listed earlier in the paper (see table1: differences) and the assumptions of the paradigm of management improvement postulated by the author have many common areas. Further in the paper, they will be confronted with the assumptions of the improvement paradigm postulated.

The first assumption postulated in the paradigm of improvement is visionary leadership. In a family enterprise, the implementation of this assumption is manifested in succession. On the one hand, it may be a source of permanence and continuation of fundamental values, on the other hand, it is one of the main causes of a short life span of family companies [PARP 2012, s. 121].

The second assumption of the paradigm is internal and external cooperation. As shown in table 1, family enterprises are characterized by a specific organizational culture manifested in creation of a positive atmosphere at work for all employees and personalized relations with employees (sixth assumption), which, among other things, lead to higher work effectiveness (internal cooperation). In the area of 
contacts with customers (stakeholders), it is characterized by high flexibility and involvement (seventh assumption).

Another assumption of the paradigm postulated is learning. The specificity of family enterprises and awareness among family members that stability of the organization has impact not only on their income but also on the future of the other members of the family creates a special kind of motivation to search for new ways of learning.

Thus, as was pointed out above, there is a high degree of compatibility between the features characteristic for family companies and the paradigm of management improvement.

However, due to the fact that the process of achieving perfection by an organization through shaping its processes may take place at various levels, maturity of individual organizations in terms of perfection may vary. Figure 1 presents a proposed thus, as was pointed out above, there is a high degree of compatibility between the features characteristic for family companies and the paradigm of management improvement.

However, due to the fact that the process of achieving perfection by an organization through shaping its processes may take place at various levels, maturity of individual organizations in terms of perfection may vary. Figure 1 presents a proposed model of maturity of an organization management improvement.

Figure 1. Model of maturity of an organization management improvement

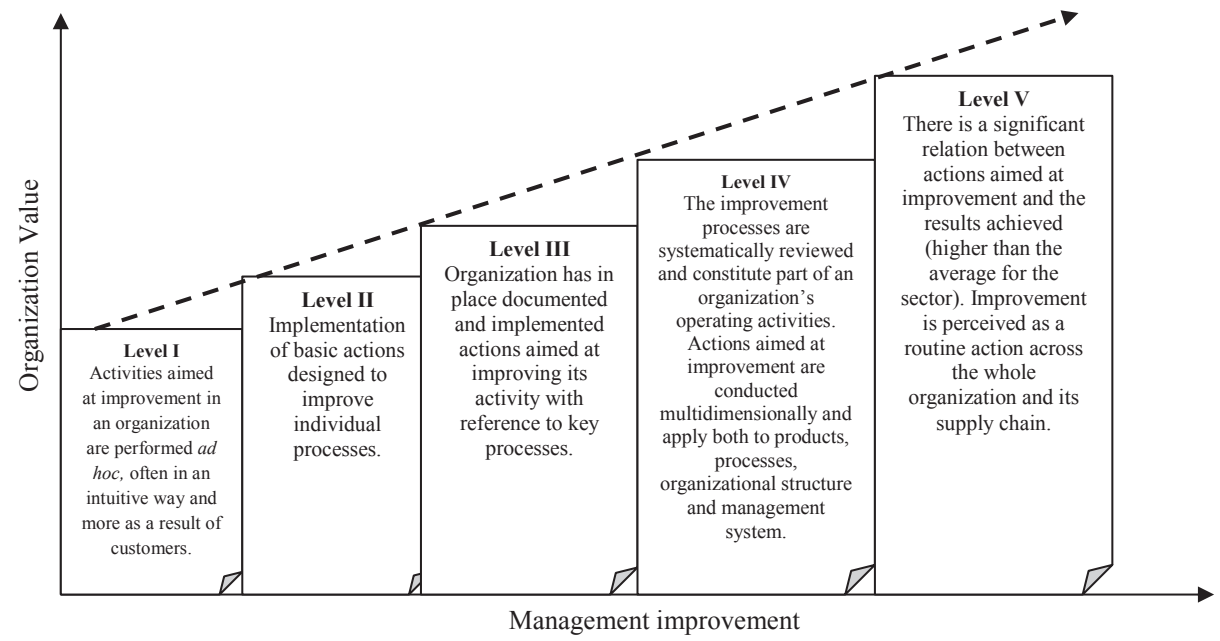

Source: own study based on: PN-EN ISO 90042010 
It distinguishes 5 levels of achieving perfection in management by an organization in the context of value increase.

The first level represents a situation where activities aimed at improvement in an organization are performed ad hoc, often in an intuitive way and more as a result of customers' (or other stakeholders of the organization) reaction than internal needs (wishes).

The second level illustrates a situation where an organization has already taken first actions in the area of improvement, such as implementation of basic actions designed to improve individual processes. Most often, they include introduction of corrective actions to prevent the errors that were already discovered or reported by the stakeholders.

At the third level, an organization has in place documented and implemented actions aimed at improving its activity with reference to key processes. Moreover, the direction of these actions is in line with the strategy adopted and organization's goals, and the process of improvement is conducted at the strategic level.

The fourth level represents a situation where the outcomes generated in an enterprise from the processes of improvement become a source of achievements (values) of the organization. The improvement processes are systematically reviewed and constitute part of an organization's operating activities. Actions aimed at improvement are conducted multidimensionally and apply both to products, processes, organizational structure and management system.

The last, fifth, stage of the model represents a situation of a perfect enterprise. Improvement isn't here the result of requirements but internal needs (wishes) of the organization. There is a significant relation between actions aimed at improvement and the results achieved (higher than the average for the sector). Improvement is perceived as a routine action across the whole organization and its supply chain. Improvement is oriented towards increasing the organization's performance and is associated with its ability to learn and implement changes.

\section{Conclusion}

The paradigm of improvement postulated by the author has already been present, though unnamed, in examination and discussions in the field of management (also in cross-cultural view). However, the way of achieving perfection in this area has evolved over the years. Among the models and tools provided by management sciences, one of the attempts to solve this problem is the model of Continuous Improvement Management (CMI). Continuous Improvement Management is a corrective tool which allows a company to adapt to the changes in its environment and a tool to improve its processes. The use of $\mathrm{CMI}$ in the industry has proven that continuous improvement management leads to the achievement of better results and increase in an enterprise's competitiveness in the environment in which modern 
organizations operate***. As M. Bednarek [2009, ss.29-33] points put, the CMI model may be presented as a process of continuous implementation in an enterprise of a set of methods, tools and philosophies, which is changeable and depends on individual characteristic features of a given company, selected and implemented depending on the changes within the enterprise and in its environment. Thus, the concept of CMI fits the conditions in which modern family organizations function and confirms the validity of the paradigm of improvement. The practice of the operation of family enterprises provides evidence that their specific features fit the paradigm of improvement in a special way.

\section{References}

Arystoteles (1996. Metafizylka, księga Delta V, 16, 1021 b 12 n. t.1, tłum. T. Żeleźnik. Lublin: Wyd. KUL.

Bednarek, M. (2009). Continuous Improvement Management. Przedsiebiorstwo przysžtości, nr 1.

Bloom, N., Van Reenen, J. (2006). Measuring and explaining management practices across firms and countries. CEP Discussion Paper No 716. London: Centre for Economic Performance London School of Economics and Political Science.

Brenes, E., Madrigal, K., Molina, G. (2006). Family business structure and succession: critical topics in Latin American experience. Journal of Business Review, nr 59(3).

Broniewska, G. (2007). Cykl PDCA odzwierciedleniem klasycznego cyklu zorganizowanego działania. Problemy Jakości, nr 7.

Claver, E., Rienda, L., Quer, D. (2009), Family firms international commitment: The influence of family-related factors. Family Business Review, nr 22.

Ejdys, J. (2011). Model doskonalenia znormalizowanych systemón zarzadzania oparty na wiedzy. Białystok: Oficyna Wydawnicza Politechniki Białostockiej.

Gorzeń-Mitka, I. (2007). Ryzyko w eksporcie. Metody i sposoby ograniczania. Warszawa: Wydawnictwo KeyText.

Gorzeń-Mitka, I. (2013a). Risk Identification Tools - Polish MSMES Companies Practices. Problems of Management in the 21st Century, nr 7.

Gorzeń-Mitka, I. (2013b). Problemy doskonalenia zarzadzania pržedsiebiorstwem. Częstochowa: Sekcja Wydawnictw Wydziału Zarządzania Politechniki Częstochowskiej.

Gorzeń-Mitka, I. (2013c). Zarz̨adzanie ryzykiem we wžroście wartości organizacji. [W:] Ziółkowska, B. (red.). Wybrane problemy z teorii $i$ praktykei zarzadzania wartościa w pržedsiebiorstwie. Częstochowa: Sekcja Wydawnictw Wydziału Zarządzania Politechniki Częstochowskiej.

Gospodarek, T. (2012). Aspekty ztożoności i filozofí nankiw zarzadzaniu. Wałbrzych: Wydawnictwo Wałbrzyskiej Wyższej Szkoły Zarządzania i Przedsiębiorczości.

Grudzewski, W.M., Hejduk, I.K. (2011). Przedsiębiorstwo przyszłości. Zmiany paradygmatów zarządzania. Master of Business Administration, nr 1.

*** This is confirmed by the experience of companies such as Bosch, DelcoRemy, Mabe-GE,

Eagle Pitcher, Mittal, Valeo czy General Motors. 
Jamali, D. (2005). Changing management paradigms: implication for educational institutions. Journal of Management Development, $\mathrm{nr} 24$.

Kuhn, T.S. (1970). The Structure of Scientific Revolutions. 2nd ed. Chicago-London, The University Of Chicago Press.

Lisiecka, K. (2006). Sposoby utrzymywania przewagi konkurencyjnej firmy. Katowice: Wydawnictwo Akademii Ekonomicznej i RWTUV Polska.

Mine Karataş-Özkan, K., Nicolopoulou, Gözde İ. And M. Özbilgin, (2011). Cross-cultural perspectives of diversity within family businesses. International Journal of Cross Cultural Management August, 2011 vol. 11 no. 2 107-111 doi: 10.1177/1470595811419005

Okręglicka, M. (2013). Dostępność finansowania bankowego a rozwój matych i średnich pržedsiębiorstw w Polsce. [W:] I.Gorzeń-Mitka (red.). Problemy doskonalenia zarzadzania przedsiębiorstwem. Częstochowa: Sekcja Wydawnictw Wydziału Zarządzania Politechniki Częstochowskiej.

PARP (2012). Firma $w$ rodzinie czy rodzina $w$ firmie. Metodologia wsparcia firm rodzinnych. Warszawa: Polska Agencja Rozwoju Przedsiębiorczości.

Peters, T. J., Austin, N.(1985). A Passion for Excellence - The Leadership Difference. London: HarperCollins Publishers, UK.

Peters, T. J., Waterman, R.H. (1982). In Search of Excellence - Lessons from America's Best-Run Companies. London: HarperCollins Publishers.

Rungtusanatham, M., Forza, C., Filippini, R., Anderson, J.C. (1988). A replication study of a theory of quality management underlying the Deming management method: insights from an Italian context. Journal of Operations Management, z. 17, nr 1.

Sipa, M. (2012). CSR w działalności małych przedsiębiorstw. Handel Wewnętrzny, lipiecsierpień T.1.

Sipa, M. (2013). Ograniczenia wplywajace na wdrożenie innowacji przez mate podmioty gospodarcze - aspekt niepowodzenia. [W:] I.Gorzeń-Mitka (red.). Problemy doskonalenia zarzadzania przedsiębiorstwem. Częstochowa: Sekcja Wydawnictw Wydziału Zarządzania Politechniki Częstochowskiej.

Słowiński, B. (2009). Inżynieria Zarz̨qdzania Procesami Logistycznymi. Koszalin: Wydawnictwo Uczelniane Politechniki Koszalińskiej.

Sułkowski, Ł. (2013). Paradygmaty nauk o zarządzaniu. Wspótczesne Zarz̨adz̧anie, nr 2.

Sułkowski, Ł. red. (2010). Zarządzanie międzykulturowe w teorii i praktyce. Præedsiębiorczość $i$ zarzqdzanie, t.11, z. 3 .

Sułkowski, L., Marjanski, A. (2009). Firmy rodżinne jak osiagná́ sukces w sztafecie pokoleń. Warszawa: Wydawnictwo Poltext.

Tatarkiewicz, W. (1976). O doskonałości. Warszawa: Państwowe Wydawnictwo Naukowe.

Yildirim-Öktem, Ö, Üsdiken, B. (2009). Contingencies versus external pressure: Profesionalization in boards of firms affiliated to family business groups in late-industrializing countries. British Journal of Management, 714-729. 
Web references

Family Firm Institute (2014). Global data points, http://www.ffi. org/?page= GlobalDataPoints [15 luty 2014].

Lewandowska A. (red.) (2013), Kody wartości - efektywna sukcesja w polskich firmach rodzinnych, http://www.kodywartosci.pl/badania.html [20 luty 2014].

PwC (2008), Skuteczne działanie. Badanie przedsiebiorstw rodzinnych 2007/08 przeprowadzone przez. Pricewaterhouse Coopers http://www.pwc.pl/pl_PL/pl/publikacje/raport_fbspl.pdf [20 luty 2014]. 